\begin{tabular}{|c|c|c|c|c|c|c|}
\hline \multirow{4}{*}{ Impact Factor: } & ISRA (India) & $=3.117$ & SIS (USA) & $=0.912$ & ICV (Poland) & $=6.630$ \\
\hline & ISI (Dubai, UAE & $=0.829$ & РИНЦ (Russia) & $=0.156$ & PIF (India) & $=1.940$ \\
\hline & GIF (Australia) & $=0.564$ & ESJI (KZ) & $=\mathbf{5 . 0 1 5}$ & IBI (India) & $=4.260$ \\
\hline & JIF & $=1.500$ & SJIF (Morocco) & $=5.667$ & & \\
\hline
\end{tabular}

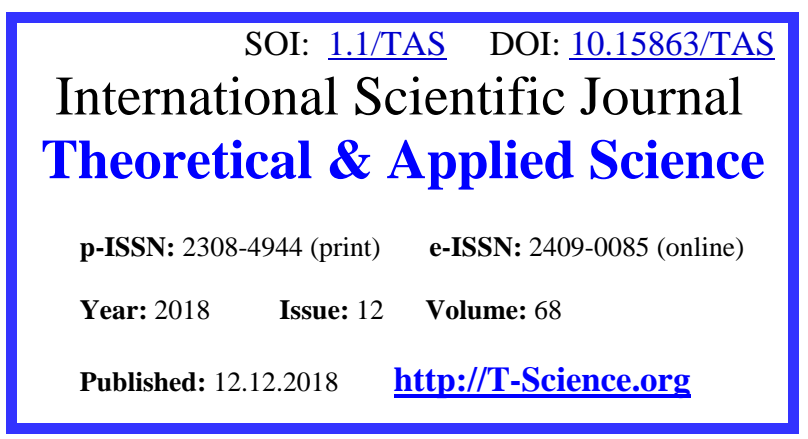

SECTION 29. Literature. Folklore. Translation Studies. Linguistics.
QR - Issue
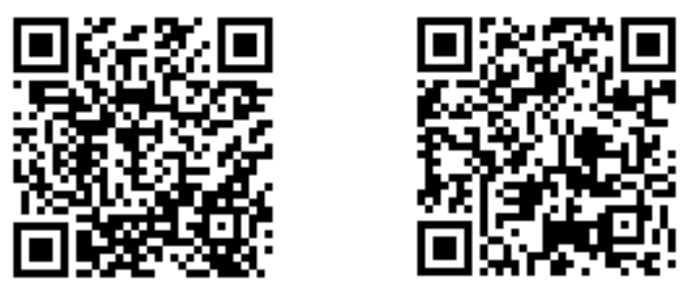

Aytan Agamirza Yadigarova ESL teacher of Modern Education Complex named after Haydar Aliyev, doctorant of Azerbaijan University of Languages Baku, Azerbaijan Republic nauka-xxi@mail.ru

\title{
THE HISTORICAL REVIEW TO AZERBAIJANI LANGUAGE AND NATIONAL LEADER HAYDAR ALIYEV'S ROLE IN THE DEVELOPMENT OF THE LANGUAGE
}

\begin{abstract}
The article named "The historical review to Azerbaijani language and the national leader Haydar Aliyev's role in the development of the language" gives short chronology of Azerbaijani language history, its fall and rise, the stages within the periods of development that language face during the occupation by different invaders, the influence of other languages and establishment as well as development of the language as the national language, the national leader Haydar Aliyev's role in the development of the language, the president of Azerbaijan republic Ilham Aliyev's decrees on the improvement of native language. In addition to above mentioned the article shows the president of Azerbaijan Republic Ilham Aliyev's decrees about carrying out of mass publications in Azerbaijani language with Latin script January 12, 2004 - The list of the books provided for republication in the first instance in Azerbaijani language with Latin script September 18, $2008-A$ decree of the President of the Republic of Azerbaijan on financing of the publication of works of the prominent representatives of the world literature in Azerbaijani language. The relevant state bodies are tasked to prepare and submit to the cabinet of the republic the State Program Project on use of the Azerbaijani language in the conditions of globalization according to requirements of time and development of linguistics in the country.
\end{abstract}

Key words: Azerbaijani language, Haydar Aliyev, historical stages, independence, development, constitution, globalization.

Language: English

Citation: Yadigarova, A. A. (2018). The historical review to Azerbaijani language and national leader Haydar Aliyev's role in the development of the language. ISJ Theoretical \& Applied Science, 12 (68), 6-10.

Soi: http://s-o-i.org/1.1/TAS-12-68-2 Doi: crossef https://dx.doi.org/10.15863/TAS.2018.12.68.2

\section{Introduction}

The Azerbaijani language is the spiritual wealth of Azerbaijan nation, unbreakable principle of the solidarity of Azerbaijanis world and one of the main symbols of the State independence.

Every Azerbaijani feels great pride in the use of Azerbaijani as the state language. In spite of the fact that Azerbaijan from time to time was forced to live under the rule of various empires, even on those days our native language was able to properly secure the existence and development of the national ideology, national consciousness and national-cultural values. Nowadays, the protection and take care of the native language is the sacred duty of every citizen in Azerbaijan.

Our native language is characterized by its rich expression; smooth sound and invariable grammar structure. Modern Azerbaijani literary language has a wide scope in political, social, scientific and cultural fields, high writing culture through enriching its vocabulary all the time. It has reached this level due to the activities of outstanding poets, novelists, as well as intellectuals. Azerbaijani Linguistics has made a great contribution to the common cause.

\section{Materials and Methods}

The Azerbaijani language is one of the languages that had passed a long path of development. Regarding the epos Kitabi Dede Gorgut as the unwritten pattern of our literature, the age of the language serving the people as a means of communication can exceed 1300 years. Some materials point out that the history of written literary 


\begin{tabular}{|c|c|c|c|c|c|c|}
\hline \multirow{4}{*}{ Impact Factor: } & ISRA (India) & $=3.117$ & SIS (USA) & $=0.912$ & ICV (Poland) & $=6.630$ \\
\hline & ISI (Dubai, UAE & $=0.829$ & РИНЦ (Russia) & $=0.156$ & PIF (India) & $=1.940$ \\
\hline & GIF (Australia) & $=0.564$ & ESJI (KZ) & $=\mathbf{5 . 0 1 5}$ & IBI (India) & $=4.260$ \\
\hline & JIF & $=1.500$ & SJIF (Morocco) & $=5.667$ & & \\
\hline
\end{tabular}

language of Azerbaijan commences with 13th century.

Azerbaijani language is the state official language of Azerbaijan and the mean of linguistic communication of the 10 million population of the country.

Besides, Azerbaijani is also spoken by 20 million Azerbaijanis living in the Islamic Republic of Iran. Several millions of Azerbaijanis living in Russia, USA, Turkey and Western Europe. Regardless of their current country of residence, Azerbaijanis still can understand each other easily. Nowadays, there are over 30 million speakers of Azerbaijani language.

From genealogically point of view, Azerbaijani language belongs to the Turkic group of languages and, together with closely associated Turkish, Turkmen and Gagauz languages, forms the southwestern group of Turkic languages.

From the traditional-morphological and typological point of view, the Azerbaijani language belongs to the group of agglutinative languages. Unlike in flexional languages, all words of Azerbaijani as well as other agglutinative languages are lexically and grammatically independent units: grammatical meanings and grammatical relations are built by mono semantic inflexions, which follow the stem and the root of a word.

The vocabulary of the language was distinguished by the predominance of words of Arabic and Persian origin. The styles of the language, especially the predominant genre of poetry and various stylistic devices caused the inflow of a great number of loan words in the literary Azerbaijani language. The establishment of schools of realism and realistic literary method and the formation of the latter as a leading creative caused disappearance of the loan words that did not join the vocabulary of the language.

The Turks who make up the ethnic foundation of the Azerbaijani people appeared in the territory of the present Azerbaijan long before our century and in the early first millennium along with other numerous tribes were the ancient residents of these lands. The appearance of a nation of Turkish origin and speaking Azerbaijani language and the transformation of this language to a means of communication was a long process, covering several centuries.

With the increase in the number of Turkish tribes as well as their economic, political and cultural influence the language was enriched and thus ethnic groups, that manage to preserve their ethnic and anthropological peculiarities even nowadays, united into a nation with a unique culture and language.

Through the 800 years of its development, the Azerbaijani literary languages had passed through two main periods. The old period covers the 13th up to 18 th century, while that one referred to as a new one started since 18th century and continues up to present times.

The first stage is notable for a vast area of the usage of the Azerbaijani language. The palace and military Azerbaijani language used by Djelairids, Qaraqoyunlus, Aggoyunlus and Sefevi states was the literary language of the Asia Minor. The Azerbaijani language of this period differed from that of the new period not by its extra linguistic and linguistic properties.

The establishment of Azerbaijani language is divided into two periods.

\section{The first period covers two stages:}

1) Formation of the literary language (13th-14th cc)

2) Flourish of the classical language of poetry (15th-18th cc)

\section{The second period covers three stages:}

1) Nationalization of the literary language (18th century)

2) Establishment and development of the national language (19th-early 20th cc)

3) Present-day stage (20th-early $21 \mathrm{st} \mathrm{cc}$ )

Each of the three stages of the second period had its own peculiarities. As mentioned above, at present, the Azerbaijani language is used not only in Azerbaijan but also in Iran and Iraq. Folklore creations testify that the languages used by Azerbaijanis living in these countries, do not differ much. However, the difference lies in literary languages and the same mainly reflected in printed literary creative works, newspapers and magazines, radio and TV programs.

When we look through history we can easily see that a war between Iran and Russia resulted in signing two agreements Gulustan (1818), Turkmenchay (1827) which divided Azerbaijan in two parts. Thus, for nearly 200 years, two parts of one nation live separately and in quite different conditions and environment. Both Iran and Russia did not admit the relations between the two parts of the nation. Though Azerbaijan established definite relations after gaining independence, yet the difference is too deep especially in languages.

Like other spheres, the difference lies also in literary language. The language of independent Azerbaijan still contains traces of Russian language, while the language of South Azerbaijan influenced by the Persian language. At present, literary language of North and South Azerbaijan still differ in vocabulary, phonetics and in some way of grammar (especially, in syntax).

Though Azerbaijan has been the part of Russia till 1991, the Azerbaijani language has been taught in secondary schools, institutes and universities for 76 years. The researches in the sphere of Azerbaijani language, its history and dialects were conducted intensively and hundreds and even more creative works were devoted. There is a possibility that the 


\begin{tabular}{|c|c|c|c|c|c|c|}
\hline \multirow{4}{*}{ Impact Factor: } & ISRA (India) & $=3.117$ & SIS (USA) & $=0.912$ & ICV (Poland) & $=6.630$ \\
\hline & ISI (Dubai, UAE & $=0.829$ & РИНЦ (Russia) & $=0.156$ & PIF (India) & $=1.940$ \\
\hline & GIF (Australia) & $=0.564$ & ESJI (KZ) & $=\mathbf{5 . 0 1 5}$ & IBI (India) & $=4.260$ \\
\hline & JIF & $=1.500$ & SJIF (Morocco) & $=5.667$ & & \\
\hline
\end{tabular}

most famous literary creations of all the nations beginning from the literature and philosophy of Ancient Greece up to present-day literary and scientific creations have been translated into Azerbaijani language. Nowadays, text-books on all school subjects (mathematics, physics, chemistry, medicine, etc.) are written in Azeri or translated from other languages. Except for one or two newspapers and magazines, Azerbaijani language almost is not used in South Azerbaijan.

In recent years the formation and development of language of those living in different countries has been influenced by the attempt to bring it closer to the literary language of Azerbaijan and the process is hoped to be successful.

As we see from above mentioned information, Azerbaijani language has been influenced by many cultures thought the history. There were interruptions, for instance, when the Arabian came, their language came into use in our country, or when the Persians came, the same thing has happened. However, our native language survived and approximately 500 years ago when the Safavid Dynasty (1499-1736) came into power. The first padishah (king) ruled all of Iran. His name was Shah Ismail Khatai. Khatai passed a decree that the Azerbaijani language should be used thought the whole palace as well as he tried to do it himself too. The firmest and the longest of these external influences are Persian, Arabic and Russian. Due to being occupied and settled by the above-mentioned countries, the Azerbaijani language has also been used in harmony with their languages, allowing it to borrow an excessive amount of words from their culture and in return lend words as well.

The 20th century was the flowering as well as the problematic period in the development of Azerbaijani language. At that very time, Azerbaijani language faced a great problem. Since the beginning of the century, three trends emerged in the literary Azerbaijani language. These are mainly related to the language of literary creations and press.

1. The first trend attempted to bring the literary language as closer to the colloquial language as possible. Creative activity of Molla Nasreddin magazine and its collaborators (Dj. Mamedguluzade, A.Haqverdiyev and others) prove this. These creations do not differentiate between literary language and colloquial language and dialects. Such language is more understandable to ordinary people.

2. The second trend mainly focusing on the establishment of a literary language resting on the traditions of old Azerbaijani language and the language of Osmanly Turks. This trend was mainly had been used by a number of magazines and newspapers. Yet, the people do not find it easy to understand such a language. This language almost did not differ from the old Turkish language.
3. The third trend, which propagandized the establishment of a literary language based on the norms of a literary language and understandable by everyone. This language was one not influenced by any dialect. It was created by such writers and poets as A.Shaig, Dj.Djabbarly, S.Guseyn, A.Sahhat. This situation lasted from early century till the 1930th.

At the end of the $19^{\text {th }}$ century when Azerbaijan lost its independence because of Iranian pressure, and we became a part of the Russian Empire, for the 200 years. As a result of large discussions and scientific disputes and under the recommendation of the first All-Union Turkic congress held in Baku in 1926 Azerbaijan people together with Turkic people accepted the alphabet with Latin graphic but later it was replaced with Cyrillic alphabet in 1939. This act being the logic continuation of mass repression of 30 -s pursued an object to cut short the process of national self-consciousness of Turkic people and to achieve their gradual estrangement and disconnection. Eliminating this historic injustice the National Board of the Supreme Council of the Azerbaijan Republic decreed:

1. That Law of Azerbaijan SSR "On the transfer of Azerbaijan written language from Latin into Russian alphabet" of July, 111939 to be considered from this day.

In 1945 after establishing the Azerbaijan National Academy of Sciences, Azerbaijani linguistics stepped on a new development level. With the coming into operation of an independent Institute of Linguistics in 1969, a firm background for successive achievements in our linguistics was created, by setting a course for a fast pace of development.

At 60 s and 70s of SSR period the leader of the Azerbaijani nation Haydar Aliyev was the very first who paid special attention to the Azerbaijani literary language and achieved the inclusion of the Azerbaijani language as the State language under a special amendment in the Constitution of the Azerbaijan SSR.

After regaining independence the Azerbaijani language has played exceptional importance as the State language in political-public, socio-economic and scientific-cultural life of the nation. National leader Haydar Aliyev approved two historical Decrees:

I. "Improvement of the Use of the State Language" dated June 18, 2001, and,

II. "Implementation of the Law of the Republic of Azerbaijan "On the State Language in the Republic of Azerbaijan" dated January 2003.

Due to which the scope of the literary Azerbaijani language has been broadened with the potentiality of its various methods being discovered and entirely new prospects being opened for our language skills and habits. 


\begin{tabular}{|c|c|c|c|c|c|c|}
\hline \multirow{4}{*}{ Impact Factor: } & ISRA (India) & $=3.117$ & SIS (USA) & $=0.912$ & ICV (Poland) & $=6.630$ \\
\hline & ISI (Dubai, UAE & $=0.829$ & РИНЦ (Russia) & $=0.156$ & PIF (India) & $=1.940$ \\
\hline & GIF (Australia) & $=0.564$ & ESJI (KZ) & $=\mathbf{5 . 0 1 5}$ & IBI (India) & $=4.260$ \\
\hline & JIF & $=1.500$ & SJIF (Morocco) & $=5.667$ & & \\
\hline
\end{tabular}

The role of Haydar Aliyev's personality is undeniable in the application of our native language as the state language, the enhancement of its importance and evaluation as the greatest asset of the Azerbaijani people. The introduction of Azerbaijani culture and our rich heritage to the world is one of Haydar Aliyev's invaluable merits. The fact that the 500th anniversary of Mohammed Fizuli and the 1300th anniversary of the "Dede Gorgud" epic were celebrated at the level of UNESCO, besides promoting Azerbaijani culture, led to the establishment of new forms of cooperation with the international cultural community. It was under the leadership of Haydar Aliyev that a foreign political course based on national interests and taking into the consideration the political future was defined, relationships were established with leading countries of the world and international organizations. His successful foreign policy contributed to the growing international authority of our country, which is now perceived as a reliable partner, and to its promotion as a reformist and ambitious state. Thanks to Haydar Aliyev's decisive steps in the international arena, our diplomacy has developed in high level. The sovereignty and territorial integrity of our country and the inviolability of its borders are reflected in all international legal documents. Haydar Aliyev has succeeded in having Azerbaijan, an important center of the Great Silk Road located at the crossroads of cultures and civilizations, recognized in the world as an area of tolerance. His foreign visits, meetings with political, public and religious leaders have led to the formation of a new image of our country. The words of the national leader of our people, "I have always been proud and I am proud today that I am Azerbaijani", along with being the slogan of Azerbaijanis of the world, have become the cornerstone of solidarity of our compatriots. Thanks to the consistent and goal-oriented policy pursued by Haydar Aliyev during his leadership of the independent Republic of Azerbaijan.

Within this article I would like to underline the national leader Haydar Aliyev's great and unforgettable steps in contributing Azerbaijan language as the state language of Sovet Azerbaijani when he became to lead Sovet Azerbaijan during 6070's years.

At that period the national leader of Azerbaijani people Haydar Aliyev played a great role in the declaration of Azerbaijani language as the state language of the country. His effort in 1978 during Soviet period was the first ever to designate Azeri as an official language. It is well known that Haydar Aliyev commenced his activity in the sphere of the state language with his first day of ruling the country (1969).

The National Leader Heydar Aliyev had profound knowledge of literary and colloquial Azerbaijani language, all his speeches were rich of phrases as well as he easily used its grammatical capacities, by providing the people with brilliant and unforgettable speeches.

He was perfectly aware of the fact that the respect and love he gained excited love and respect to the state language of Azerbaijan. All that created the atmosphere leading to the establishment of a state language.

In 1977-1978 the leadership of the country faced a number of problems. As we know the new Constitution of USSR was approved in 1977. That very Constitution had to be an example to the new constitutions of all the countries and in fact it did. Yet the constitution did not contain an article on a state language. The newly approved constitutions of different republic did not cover this issue either.

The National Leader Haydar Aliyev continued his struggle for the Azerbaijani language to be declared in the constitution as the state language. Attracting the intellectuals and the entire population to the struggle, he put all efforts into it and overcame all obstacles with brevity. While making a report at the seventh session of the Supreme Council of the Azerbaijan SSR, he required Azerbaijani language to be the first spoken language in the republic, as the result of his speech there was additions to the constitution of the SSR Azerbaijan. The amendment to the 73rd article was: "Azerbaijani language is the state language of the Azerbaijan Soviet Socialist Republic".

Azerbaijan Soviet Socialist Republic had to provide the usage of Azeri language in all state and social organizations, educational institutions and other establishments, as well as should promote its comprehensive development.

The constitution of 1978 proves that Haydar Aliyev really cared about his nation and his native land.

The Constitution of independent Azerbaijan, accepted through national voting confirmed Azerbaijani language as the state language of the country.

The state language of the Azerbaijan Republic is Azerbaijani language. Azerbaijan should provide all necessary works for the development of the Azerbaijani Language.

Haydar Aliyev, who always gave a great importance to his native language and had a profound knowledge of it, considering the situation, created at the turn of the new period of the state language development, signed a decree "On perfection of measures for the use of the state language" on June 18, 2001.

The above-mentioned decree, along with reflecting the achievements of the language through the history of its development also determined existing problems of the language and pointed out the ways of their resolution. 


\begin{tabular}{|c|c|c|c|c|c|c|}
\hline \multirow{4}{*}{ Impact Factor: } & ISRA (India) & $=3.117$ & SIS (USA) & $=0.912$ & ICV (Poland) & $=6.630$ \\
\hline & ISI (Dubai, UAE & $=0.829$ & РИНЦ (Russia) & $=0.156$ & PIF (India) & $=1.940$ \\
\hline & GIF (Australia) & $=0.564$ & ESJI (KZ) & $=\mathbf{5 . 0 1 5}$ & IBI (India) & $=4.260$ \\
\hline & JIF & $=1.500$ & SJIF (Morocco) & $=5.667$ & & \\
\hline
\end{tabular}

Some of these ways have already implemented successfully. The decree of President of the Azerbaijan Republic Ilham Aliyev signed on January 12, 2004 "On the publishing of mass media in Latin alphabet in Azerbaijani language will, undoubtedly, settle all the problems connected with the alphabet.

At the present the president of Azerbaijan Republic Ilham Aliyev signed a decree of the President of the Republic of Azerbaijan on the carrying out of mass publications in Azerbaijani language with Latin script January 12, 2004 - The list of the books provided for republication in the first instance in Azerbaijani language with Latin script September 18, 2008 - A decree of the
President of the Republic of Azerbaijan on financing of the publication of works of the prominent representatives of the world literature in Azerbaijani language.

With a view of maintenance of increase of the state care of use and research of the native language which is one of the main symbols of our state hood, in linguistics area in the country, the relevant state bodies are tasked to prepare and submit to the cabinet of the republic the State Program Project on use of the Azerbaijani language in the conditions of globalization according to requirements of time and development of linguistics in the country.

\section{References:}

1. Budaqova, Z. I., \& Ismailova, G. G. (1973). Orthography of Azerbaijani language. Moscow.

2. Shiraliyev, M. S. (1996). Azerbaijan Language. Baku.

3. (1971). Azerbaijan Language Grammar. Baku Academy of Sciences.

4. Sumbatzade, A. S. (1990). Azerbaijanis, enthnogenesis and formation of nation. Baku.

5. Budaqova, Z. I. (1982). Azerbaijan Language. Baku.

6. Miralamov, H., \& Adrianov, V. (2016). Heydar Aliyev from life of remarkable people. series, Baku.
7. Akhundova, E. (n.d.). Haydar Aliyev a living history. ISBN: 9789952510775.

8. Akhundova, E. (n.d.). Haydar Aliyev five years in Kremlin. ISBN: 9789952510771.

9. (n.d.). The National Leader Haydar Aliyev's Decrees about the development of Azerbaijani Language. Azerbaijan Republic Presidential Library.

10. (2004, January 12). Azerbaijan Republic President Ilham Aliyev's Decree on the carrying out of mass publications in Azerbaijani language with Latin script. 